\title{
Perception of nurse managers about the functionally-readapted worker
}

\author{
Percepção de enfermeiros gerentes sobre o trabalhador readequado funcionalmente \\ La percepción de enfermeros gerentes sobre el trabajador reasignado funcionalmente
}

\section{Gabriela Moreira Campos' \\ ORCID: 0000-0002-9242-5246}

Júlia Trevisan Martins'
ORCID: 0000-0001-6383-7981

Renata Perfeito Ribeiro'

ORCID: 0000-0002-7821-9980

Maria Lucia do Carmo Cruz Robazzi"

ORCID: 0000-0003-2364-5787

Maria José Quina Galdino"'I

ORCID: 0000-0001-6709-3502

\section{Maria do Carmo Fernandez Lourenço Haddad' \\ ORCID: 0000-0001-7564-8563}

'Universidade Estadual de Londrina. Londrina, Paraná, Brazil. "Universidade de São Paulo, Escola de Enfermagem de Ribeirão Preto. Ribeirão Preto, São Paulo, Brazil.

"'Universidade Estadual do Norte do Paraná.

Bandeirantes, Paraná, Brazil.

How to cite this article: Campos GM, Martins JT, Ribeiro RP, Robazzi MLCC, Galdino MJQ, Haddad MCFL. Perception of nurse managers about the functionally-readapted worker. Rev Bras Enferm. 2019;72(4):861-7. doi: http://dx.doi.org/10.1590/0034-7167-2017-0834

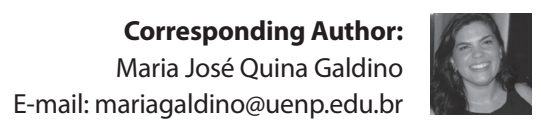

Submission: 11-02-2017 Approval: 09-29-2018

\begin{abstract}
Objective: To understand the perception of nurse managers about the functionallyreadapted worker. Methods: Descriptive study with qualitative approach, whose data were collected in from November 2016 to April 2017, through interviews with 14 nurse managers of a university hospital. The content analysis analysis was applied to interpret the speeches. Results: The reports converged into three categories, which revealed the impact on the management of the nursing staff, the management of the limitations of the readapted worker, and the regular follow-up planning for him. Final considerations: Nurse managers are clear that readapted workers need special attention, so that their potentialities mat be maximized, respecting the workers' limitations. Readapted workers must be encouraged to resume their self-esteem, identity, autonomy, and feel socially included.

Descriptors: Nursing; Workers; Occupational Diseases; Health Management; Hospitals, University.
\end{abstract}

\section{RESUMO}

Objetivo: Conhecer a percepção de enfermeiros gerentes sobre o trabalhador readequado funcionalmente. Métodos: Estudo descritivo com abordagem qualitativa, cujos dados foram coletados no período de novembro de 2016 a abril de 2017, por meio de entrevistas com 14 enfermeiros gerentes de um hospital universitário. Para interpretar os discursos utilizou-se a técnica de análise de conteúdo. Resultados: Os depoimentos convergiram em três categorias, que revelaram o impacto no gerenciamento da equipe de enfermagem, o gerenciamento das limitações desse trabalhador readequado e o planejamento de um acompanhamento regular para ele. Considerações finais: Os gerentes apresentam clareza de que os trabalhadores readequados precisam de atenção especial, para que suas potencialidades sejam maximizadas, respeitando suas limitações. Faz-se necessário estimulá-los para que retomem sua autoestima, identidade, autonomia e sintam-se incluídos socialmente.

Descritores: Enfermagem; Trabalhadores; Doenças Profissionais; Gestão em Saúde; Hospitais Universitários.

\section{RESUMEN}

Objetivo: Conocer la percepción de enfermeros gerentes sobre el trabajador reasignado funcionalmente. Métodos: Estudio descriptivo de abordaje cualitativo, en que se recolectaron los datos en el período de noviembre de 2016 a abril de 2017, por medio de entrevistas con 14 enfermeros gerentes de un hospital universitario. En la interpretación de los discursos se utilizó la técnica de análisis de contenido. Resultados: Las declaraciones convergieron en tres categorías, que revelaron el impacto en la gestión del personal de enfermería, la gestión de las limitaciones de ese trabajador reasignado y la planificación de un seguimiento regular para él. Consideraciones finales: Los gerentes entienden que los trabajadores reasignados necesitan una atención especial, para que se maximicen sus potencialidades, respetando sus limitaciones. Es necesario estimularlos para que retomen su autoestima, identidad, autonomía y se sientan incluidos socialmente.

Descriptores: Enfermería; Trabajadores; Enfermedades Profesionales; Gestión en Salud; Hospitales Universitarios. 
Perception of nurse managers about the functionally-readapted worker Campos GM, Martins JT, Ribeiro RP, Robazzi MLCC, Galdino MJQ, Haddad MCFL.

\section{INTRODUCTION}

Work is one aspect of the human condition that may occupy a position of centrality in people's life. It takes place in a social environment and is influenced by numerous factors, which determine its characteristics. The work can be configured as a source of professional and personal achievement, skills development, accumulation of wealth and material possessions and, also, of feelings of pleasure due to the service provided to society. On the other hand, it can be exhausting, frustrating and cause physical, mental, and social distress ${ }^{(1-2)}$.

When the work provides satisfaction, joy, pleasure, and growth, it is regarded as a tool that gives meaning to people's life and can represent a protection to the worker's health ${ }^{(3)}$. However, when it is pervaded by mental distress, overload of activities, fast pace, repeatability to develop activities, and lack of recognition, the work can cause high levels of wear and, consequently, induce diseases and aggravations of physical and psychic nature to workers ${ }^{(4)}$.

Professionals who work in hospital institutions, especially those from nursing, are exposed to chemical, physical, mechanical, biological, ergonomic, and psychosocial hazards, favoring their sickening that, in turn, causes temporary or permanent limitations ${ }^{(5-6)}$. In addition, a limitation may indicate the need to readjust and/or readapt these professionals.

The functional readjustment was established by the Brazilian Social Welfare in 1990, through Federal Law no. 8.112 in art. 24, which defined it as the "vesting of the servant in charge of duties and responsibilities compatible with the limitation that has been made to his physical or mental capability verified by medical inspection"(7). Therefore, this readjustment represents a way to meet the needs of the worker who, despite the functional limitation, can still be active to develop activities that are compatible with his or her new state, since a restraint acquired in work is not a reason for resignation, since there is a constitutional and legitimate provision for functional readaptation. It is believed that this situation may interfere in the readapted person's interpersonal relationship with team members with whom he or she will work, which may affect even more his or her health and lead to a greater mental distress ${ }^{(8)}$.

Thus, on the one hand, the law protects and ensures guarantees to workers; on the other, under various perspectives, the managers need to lead this complex situation, in order to maximize the worker's potential without failing to meet the needs of the institution. In this sense, a study developed in a university hospital identified that readjusting workers causes a strong impact on the work of nurse managers due to the several developments that the situation causes, demanding management skills and competence in order to integrate this worker into the nursing and health team ${ }^{(9)}$.

Given this scenario, to understand and reflect on the functional readaptation according to the nurse managers' perception is relevant because this process identifies implications of personal, social, and managerial nature, with repercussions for the worker as well as for the care provided to patients and their family. Still, studies on the subject are scare, even though workers in this condition represent a growing reality in hospital institutions, which makes necessary the preparation of all those involved to face this new situation. Thus, the following question is posed: what is the perception of nurse managers about the functionallyreadapted worker?

\section{OBJECTIVE}

To understand the perception of nurse managers about the functionally-readapted worker.

\section{METHODS}

\section{Ethical aspects}

This study was developed in accordance with ethical principles in force, being approved by the Research Ethics Committee of the State University of Londrina. All the participants signed the Informed Consent Form (ICF) and, for preservation of anonymity, the interviews held with them were identified with the letter " $G$ " and numbered according to the sequence in which they occurred.

\section{Study type and scenario}

Descriptive study of qualitative approach held in a university hospital in Paraná. This is one of the largest teaching hospitals in the South Region of Brazil, with 306 beds, serving people of all life cycles through the Unified Health System (SUS). In this institution, approximately $6 \%$ of nursing workers are functionally readapted or readjusted.

The study population consisted of nurse managers of the nursing services responsible for the management of administrative, assistance, and teaching/research areas, aiming at the quality care and well-being of human resources. The inclusion criteria were: being a nurse, occupying the position of manager for at least one year, and presenting at least one readapted worker in the work team. The exclusion criterion was being in usufruct of license of any kind.

The number of participants was determined by the criterion of data saturation, which occurred with 12 respondents, but researchers opted to continue the collection because there were only two more nurses to be interviewed. Therefore, this study included 14 nurse managers.

\section{Data collection and organization}

From November 2016 to April 2017, in the interviewer's workplace in a reserved room in date and time scheduled by the participants, the data was collected by interviews held by the first author, with the following guiding question: What is your perception about readapted nursing workers? The interviews were recorded, lasted 30 minutes on average, and soon after its conclusion, were transcribed in full.

\section{Data analysis}

Depositions were analyzed by thematic content analysis, following the phases of pre-analysis, exploration of the material, treatment and interpretation of the results obtained ${ }^{(10)}$. Initially, a floating and thorough reading of interviews was held for familiarization, i.e. a 
Perception of nurse managers about the functionally-readapted worker Campos GM, Martins JT, Ribeiro RP, Robazzi MLCC, Galdino MJQ, Haddad MCFL.

first approximation with the text, in order to understand what the respondents sought to convey. Then, the thematic selection was made, identifying the nuclei of meaning or semantically-similar elements to subsequently start the categorization and analysis ${ }^{(10)}$.

To analyze the data, the theoretical assumptions used were based on the understanding that the process of managerial work, as well as the labor objects of the nurse, must be the work organization and human resources of nursing. This study also considered that there is a connection between management and assistance, in which the real care needs of patients are sought at the same time that the needs of the nursing and of the healthcare institution are considered ${ }^{(11)}$.

\section{RESULTS}

Considering the nurse managers interviewed, 11 were female and three were male. On average, they were 46 years old, had 23 years of training, and 16 years working in the institution under study.

Units of meaning emerged from their depositions and were grouped into eight themes, which converged into three categories listed below.

\section{Impact on team management}

In this category, respondents reported that the "conformism with the situation," the "matter of institutional policy," and the"non-acceptance and the prejudices of the team," are seen as impacting aspects for managing the labor activities, as indicated by the depositions:

It is better to have a readapted worker in the hospital performing assignments within his functional capacity than have him at home with a certificate, since the human resources are few and with him I can count on, even with limitations. (G1)

It is a major impact to manage, since we already have lack of human resources. (G2)

We have to accept the situation because we have no way out; it is better to have a readapted employee than none. (G3)

It has to be treated as an institutional policy, because the headship is unequal; each one carries inside a professional experience and an own vision of the world, and on the other side, we must include them, because if we rely only on the managers, each will treat the problem with their singular worldview, within their singular experience. (G6)

The teams have difficulty in accepting readapted workers because they are afraid of being overloaded. Only time and hard work of the managers to overcome this difficulty. (G8)

Teams have prejudices with readapted workers. (G11)

\section{Managing the limitations of the worker}

The themes "enhance the capabilities, putting yourself in the place of the other" and "awakening the readapted worker to his/ her capabilities" were important points revealed by the nurses and managers that need to be observed in the management, as one can note in the speeches:
We have to see what are the limitations, because they cannot be excluded from the work process and the big challenge is to find where we can enhance this worker, but sometimes we are unprepared for it. (G5)

I have to take advantage of the best this person has to offer: if the physique is the weakness, he has the intellectual, or vice versa. (G7)

We must show to the readapted worker that he has possibilities and skills to various activities. Everything is a matter of finding the appropriate place so that he can develop the most within his limitations. (G13)

Whenever I am with the nurses that have readapted employees on the team, I think that one day it could be me, or a closer colleague, and I reflect on this in an attempt to find solutions together. (G9)

Several readapted workers do not value their work capacity; they think they do not "fit" for anything anymore, so we must invest so that they can value themselves and may see within their limitations how they still have potential. (G12)

\section{Planning a regular monitoring}

In this category emerged the themes "create support networks" and "constant meetings with the readapted worker and with the team" as practices to be implemented for provision of support and appropriate monitoring of workers in the condition of functional readjustment, as the following depositions revealed:

Something I have always wanted to do is a support network with the multidisciplinary team, to hear and be heard by these workers. (G8)

I believe that the systematic scheduling of the meetings will facilitate the inclusion of the readapted workers on the team, we need to hear them and they need to listen to us too. (G14)

We need to meet these workers at least every three months because some have reports that are due and we do not have the opportunity to monitor them; it would be interesting to have a rapprochement. (G10)

I think that it is essential for us to have regular meetings with the readapted employees, but also with the whole team, so we can, in fact, know the difficulties and the facilities to draw together plans. (G13)

\section{DISCUSSION}

With regard to the participants' profile, it is known that there is a predominance of women in the work of nursing, a characteristic fact in the history of the profession and in the feminization of the care in healthcare institutions. However, a gradual increase in males in nursing has been occurring. The training time allied to the working time in a single work are important factors to improve the interpersonal relationship in health services through communication and recognition of workers' issues ${ }^{(12)}$.

In relation to the category "impact on team management", it became evident that the respondents have to manage the scarce human resources; thus, they prefer to have a worker in readjustment condition rather than not having him. The repercussions arising from the leaves of nursing workers for illness/certificate can be translated as overload of team activities, since there is no way to foresee the replacement of a professional in situations of unpredictability ${ }^{(13)}$. 
It was also highlighted the need for the institution to have a planned and formalized proposal to meet the needs of the readapted worker, being responsible for creating a stream of reception of these workers in the places where they were inserted, in order to contribute to a safe and motivating environment. The participation of all those involved in the decisions is of crucial importance, that is, the readapted worker and nursing team, along with the management planning of human resources. This institutional planning appears in a strategy that may contribute to obtain more efficient results, with respect to the reintegration of the readapted worker to the work, his peer acceptance, the rescue of his self-esteem and his identity ${ }^{(14)}$.

When nursing team and managers receive the readapted worker and understand the difficult process that he faces, they are contributing to improve his self-esteem and self-confidence. To provide a suitable working environment for the limitations of the readapted worker is also a strategy to prevent new diseases, aggravations, and recurrences. Consequently, the planning and the involvement of all who take part in this process, responsible for the systems and services, will provide better conditions for the return and adaptation to the labor of workers that are undergoing readjustment or are already readjusted ${ }^{(15)}$.

It is worth mentioning that the process of functional readaptation is facilitated when the work team receives the readapted professional without prejudice or hostility, offering him social and affective support, a fundamental factor for relationships and easiness in the reintegration process ${ }^{(16)}$. Therefore, the nurse manager has the role of acting as moderator and facilitator of this process.

It is a fact that nurse managers must have attitudes and behaviors compatible with the institution, as well as they are expected to instrumentalize the team to maximize the interpersonal relationships and seek spaces for everyone to participate in the process of negotiation to conciliate differences, striving to obtain the autonomy of each worker, but without losing control of this process ${ }^{(17)}$. For readapted workers it is no different, however with a special attention added, because it involves singular and complex situations.

Among the many functions of the nursing managers, there are highlighted the assignments of taking care directly or indirectly of the patients and their family members. However, one cannot deny that, increasingly, the ability to work in team are demanded from these professionals in order to improve the assistance provided. Managing the work team flexibly and listening to everyone is relevant; in particular, it is necessary to be aware of the reality of readapted worker, a category that has grown in healthcare institutions.

On the other hand, workers need to learn how to interact with their teammates, because teamwork is not involuntary, instinctive, but requires the development of skills and capacities of everyone involved ${ }^{(18)}$. In this sense, readapted workers need to be included in the work teams by nursing managers and accepted by their peers, so there is the possibility of establishing and achieving the common objectives and goals proposed, respecting the individual limits of each worker and, as a result, providing quality care for patients and their family members.

The nurses who occupy management functions must exercise the role of leaders in nursing teams and, thus provide the inclusion of the functionally-readapted worker. In this way, the expectation is for them to act in order to ensure the well-being of the team, promoting an atmosphere of friendship, mutual help, and solidarity that keep conflicts under control and together prepare the positive directions for the labor ${ }^{(19)}$.

In the second category "managing the limitations of the worker", the lines of the interviewees show the challenges that nurse managers have to administer the limitations of readapted workers, seeking to enhance their capabilities to the extent possible. It is evident that there still lacks training or preparation of health professionals, more specifically of nurse managers and human resources professionals, with regard to the service, monitoring, and guidance on the clinical and social aspects, as well as on the rights of these workers, so everything can be formalized and they are accepted within the institution ${ }^{(20)}$. Therefore, every healthcare professional in the institution must be trained to receive and include the readapted professionals, enhance their potentialities, and respect their limitations, which reflects the principle of comprehensiveness advocated by the SUS.

So that managers can receive and include the readapted worker, they must be aware of their limitations. For that, they need to know, through reports of official medical boards, what are the health restrictions that the worker has to have clarity of which activities he may or may not perform; so that they can adapt them according to his limitations of physical or mental nature. In this context, nurse managers should avoid exposing the worker to situations that may aggravate the health condition or offer risks to third parties ${ }^{(21)}$. Being in accordance with the legislation and labor restrictions is important to protect the institution, the patients and their family members, as well as the readapted individual himself, avoiding losses and unnecessary damage.

Through investigation, it is possible to identify which activities the employee is able to develop, consistent with the assignments of his post, due to the limitation that the illness or injury caused; thus, the management will know those that should be avoided ${ }^{(7)}$.

When one thinks about labor readjustment or leave, he or she must break with the paradigm of understanding them only as a threat of disruption to the services and to the employee. It is necessary to specify the potentialities and provide strategies for professionals so they can create new ways of developing their activities and thus produce new senses for the everyday work, given that the readjustment does not end in the clinical disorders, i.e. in the causes that triggered the illness, focusing on biomedical factors. Readjustment is a broad and complex process that affects people's lives. Thus, one must understand the sense of labor leave, considering the effects of the disruption process suffered by the worker ${ }^{(22)}$.

Another aspect that managers focused on refers to the readapted workers' own acceptance with the new condition. This worker has, in most cases, difficulties in accepting the limits that the disease caused in his working and even private life and, in some situations, he offers himself to perform activities that are configured as surplus to their possibilities and he also accepts them, being unable to deny what is requested. The readapted worker masks and hides the symptoms of his illness, in an attempt of answering what was requested from him, or even imposed to him, increasingly exacerbating his clinical condition ${ }^{(16)}$.

However, to avoid this kind of situation, the nursing team and managers must receive him, prepare a reception course in the place where he is inserted, aiming to contribute to a secure and motivating environment. Therefore, this worker must be stimulated 
to work with self-confidence and self-esteem, without the need to mask his weaknesses to develop activities of daily living ${ }^{(16,22)}$.

When the nurse manager reflects that everyone is exposed to risks in the workplace and that one day his own self or of one teammate could be in this position of needing functional readjustment, he reveals sensitivity and concern for his team. Empathy is complex, involves affective, cognitive and communicative components and presents itself as an essential tool to be used by leaders. The empathetic leadership is based on the conception that people are connected to each other and that the society survives due to the human being's ability of feeling the other and reacting to $i^{(23)}$.

Empathetic leaders create emotional bonds and thus are able to understand the needs of their teams, respecting the talents and acknowledging the perspective of the other to make decisions. In this way, a space for a culture of trust, mutual respect and cooperation among those involved is opened, creating perspectives of relational leaderships, shared and collaborative ${ }^{(23)}$.

A study showed that empathy works as the first big emotional support, being the description the second behavior of support communication that contributes to the relational satisfaction, by clearly showing the desire of workers for an objective communication, with established function and duties. When using the communication, leaders can help the employee to feel more predisposed to a good relationship (24).

In this same study, the transformational leadership was predicted by several behaviors of support communication, including empathy, guidance to the problem, and description. Transformational leaders are concerned with the well-being and development of their work team, given that the description, the empathy, and the spontaneity are configured in statistically significant and more frequent predictors of the leader's effectiveness and of the satisfaction in the relationship and in the work of people ${ }^{(24)}$.

Nurse managers must value and execute communication, excel for healthy interactions, and be sensitive to cope with the needs of workers and patients ${ }^{(25)}$.

In the third category "planning a regular monitoring", managers indicated the need for a constant monitoring of these readapted workers, through meetings. It is important to note that the social support should be seen as essential in the functional readjustment given that, in general, it can function as mutual assistance, cooperation, and encouragement among all those involved who live with the other on a daily basis, building meanings in their everyday experiences contexts ${ }^{(26)}$.

For an efficient management, in which all those involved can participate, managers must listen and talk to the nursing team. Therefore, it is necessary to establish links and build cooperative networks in which there is collective participation in the management process. This will only be possible when the appreciation of the subjects involved in this support network happen ${ }^{(27)}$.

To hear and to be heard also represent ways to seek solutions to the problems. Dialogue and shared decisions need to compose the culture of healthcare organizations, with the purpose of improving the interpersonal relationship and the labor process. Furthermore, beyond recognition by their peers, the employees aim policies and managements that make more responsive and accessible the solution of situations that involve or affect their health ${ }^{(1)}$.

Thus, it is important to develop collective actions to reduce factors that are harmful to workers'health, in particular, actions for stress relief, well-being, and friendly organizational climate in order to enhance the quality of life at work and the humanization in labor processes ${ }^{(2,4)}$.

The research added the importance of managerial actions and health policies to include workers who present impaired health conditions and the creation of an inclusive, supportive, and beneficial environment for all those involved, because then the well-being will pervade the workplace ${ }^{(28)}$.

Nurse managers need to provide a continuous attention to the readapted worker, who may be insecure about his place and the activities to be developed, as well as can present difficulties of being included as a member of the group. Therefore, managers need to schedule meetings to assess this situation, seeking ways to reconstruct the worker's professional identity. In this sense, colleagues, managers, and immediate leadership are essential to provide social support, an important element in professional relationships and fundamental to the reinsertion process ${ }^{(18)}$.

\section{Study limitations}

Although this study has reached its goal, a possible limitation is the restriction of the field, given that only the opinion of nurses from a teaching hospital about their managerial experiences with these workers were considered. Still, the scarcity of recent studies on the subject is also a limitation.

\section{Contributions to the fields of nursing and health}

Functional readaptation is a growing reality in health care institutions that, due to the complexity of the process, requires appropriate management actions. The evaluation of the nurse managers' perception about the subject allowed the study to identify the need of establishing an institutional policy to manage the case, the reception of the worker on the team, the creation of social support networks, and the monitoring of the readapted workers, as well as the need of inserting him into a new activity that does not aggravate his condition, but that enables his professional development.

Still, the findings of the study allow one to reflect on the need of inserting in the curricular grids of undergraduate courses in nursing the managerial situations experienced in the everyday lives of healthcare institutions, related to functional readjustment, especially in the environment of hospitals.

\section{FINAL CONSIDERATIONS}

Nurse managers are clear that readapted workers need special attention so that their potentialities may be maximized, respecting the workers'limitations. Readapted workers must be encouraged to resume their self-esteem, identity, autonomy, and feel socially included.

On the other hand, so that this situation does not become trivialized or crystallized as a problem without resolution and relevance, it is important to create support networks within the services to develop actions towards these workers. It becomes essential to monitor these professionals, reflect together with managers and workers about actions for inclusion, health promotion, and reduction of the aggravations, and thus improve the quality of life of the readapted workers that, consequently, will provide better care to their patients and family members. 


\section{REFERENCES}

1. Santos JLG, Prochnow AG, Silva DC, Silva RM, Leite JL, Erdmann AL. Pleasure and suffering in nursing management in the hospital context. Esc Anna Nery. 2013;17(1):97-103. doi: http://dx.doi.org/10.1590/S1414-81452013000100014

2. Martins JT, Ribeiro RP, Bobroff MCC, Marziale MHP, Robazzi MLCC, Mendes AC. Meaning of workload on the view of cleaning professionals. Acta Paul Enferm. 2013;26(1):63-70. doi: http://dx.doi.org/10.1590/S0103-21002013000100011

3. Dejours C. A loucura do trabalho: estudo da psicopatologia do trabalho. São Paulo: Cortez; 2003.

4. Cacciari P, Haddad MCFL, Wolff LDG, Dalmas JC, Pissinati PSC. Quality of life of workers who underwent work adjustments and adaptations in a public state university. Rev Gaúcha Enferm. 2017;38(1):e60268. doi: http://dx.doi.org/10.1590/1983-1447.2017.01.60268

5. Porto JS, Marziale MHP. Reasons and consequences of low adherence to standard precautions by the nursing team. Rev Gaúcha Enferm. 2016;37(2):e57395. doi: http://dx.doi.org/10.1590/1983-1447.2016.02.57395

6. Sousa AFL, Queiroz AAFLN, Oliveira LB, Moura MEB, Batista OMA, Andrade D. Social representations of biosecurity in nursing: occupational health and preventive care. Rev Bras Enferm. 2016;69(5):864-71. doi: http://dx.doi.org/10.1590/0034-7167-2015-0114

7. Presidência da República (BR). Lei Federal n 8.112, de 11 de dezembro de 1990. Dispõe sobre o regimento jurídico dos servidores públicos civis da União, das autarquias e das fundações públicas federais. Diário Oficial da União [Internet]. 1991 Apr 4 [cited 2017 Oct 27];1:1. Available from: http://www.planalto.gov.br/ccivil_03/leis/L8112cons.htm

8. Cavalcante MS. Aspectos polêmicos do instituto de readaptação funcional no âmbito da administração pública. Rev Controle [Internet]. 2011 [cited 2017 Oct 27];9(2):171-92. Available from: http://revistacontrole.ipc.tce.ce.gov.br/index.php/RCDA/article/view/142/143

9. Cacciari P, Haddad MCL, Vannuchi MTO, Marengo RA. Socio demographic and occupational characterization of readjusted and rehabilitated nursing staff. Rev Enferm UERJ [Internet]. 2013 [cited 2017 Oct 27];21(3):318-23. Available from: http://www.e-publicacoes.uerj.br/index. php/enfermagemuerj/article/view/7462

10. Bardin L. Análise de conteúdo. Lisboa: Edições 70, 2016.

11. Kurcgant P. Gerenciamento em enfermagem. 3rd ed. Rio de Janeiro: Guanabara Koogan; 2016.

12. Matos IB, Toassi RFC, Oliveira MC. Heath professions and occupations and feminization process: trends and implications. Athenea Digital [Internet]. 2013 [cited 2017 Oct 27];13(2):239-44. Available from: https://www.lume.ufrgs.br/bitstream/handle/10183/118035/000894801. pdf?sequence $=1$

13. Lucca SR, Rodrigues MSD. Absenteeism of professional nursing in a public hospital in the state of São Paulo. Rev Bras Med Trab [Internet]. 2015 [cited 2017 Oct 27];13(2):76-82. Available from: http://www.rbmt.org.br/details/7/pt-BR/ absenteismo-dos-profissionais-de-enfermagem-de-um-hospital-universitario-do-estado-de-sao-paulo--brasil

14. Theme Filha MM, Costa MAS, Guilam MCR. Occupational stress and self-rated health among nurses. Rev Latino-Am Enfermagem. 2013;21(2):475-83. doi: http://dx.doi.org/10.1590/S0104-11692013000200002

15. Toldrá RC, Daldon MTB, Santos MC, Lancman S. Facilitating factors and barriers for returning to work: the experience of workers treated at a workers' health reference center in São Paulo, Brazil. Rev Bras Saúde Ocup. 2010;35(121):10-22. doi: http://dx.doi.org/10.1590/ S0303-76572010000100003

16. Cestari E, Carlotto MS. Professional rehabilitation: what the worker thinks about their reintegration. Estud Pesq Psicol [Internet]. 2012 [cited 2017 Oct 27];12(1):93-115. Available from: http://pepsic.bvsalud.org/pdf/epp/v12n1/v12n1a06.pdf

17. Eduardo EA, Peres AM, Kalinowski CE, Cunha ICKO, Bernardino E. The negotiator that we have and the negotiator that we want in nursing. Texto Contexto Enferm. 2016;25(3):e1030015. doi: http://dx.doi.org/10.1590/0104-07072016001030015

18. Navarro ASS, Guimarães RLS, Garanhani ML. Teamwork and its meaning to professionals working in the family health strategy program. Rev Min Enferm [Internet]. 2013 [cited 2017 Oct 27];17(1):69-75. Available from: http://www.reme.org.br/artigo/detalhes/579

19. Duarte JMG, Simões ALA. Meanings of work to nursing professionals at a teaching hospital. Rev Enferm UERJ. 2015; 23(3):388-94. doi: http:// dx.doi.org/10.12957/reuerj.2015.6756

20. Batista JM, Juliani CMCM, Ayres JA. Retraining due to illness and its implications in nursing management. Rev Latino-Am Enfermagem. 2010;18(1):87-93. doi: http://dx.doi.org/10.1590/S0104-11692010000100014

21. Ministério do Planejamento, Orçamento e Gestão (BR), Secretaria de Recursos Humanos, Departamento de Saúde, Previdência e Benefícios do Servidor. Manual de perícia oficial em saúde do servidor público federal. 2nd ed. Brasília, DF: Ministério do Planejamento, Orçamento e Gestão; 2014. Disponível em: http://das.prodegesp.ufsc.br/files/2016/08/Manual-SIASS-\%E2\%80\%93-Per\%C3\%ADcia.pdf

22. Arbex APS, Souza KR, Mendonça ALO. Teaching, readjustment and health: the experience of teachers at a public university in Brazil. Physis. 2013;23(1):263-84. doi: http://dx.doi.org/10.1590/S0103-73312013000100015

23. Tzouramani E. Leadership and empathy. In: Marques J, Dhiman S, editors. Leadership today: practices for personal and professional performance. Basel: Springer International Publishing; 2017. p. 197-216.

24. Czech K, Forward GL. Communication, leadership, and job satisfaction: perspectives on supervisor-subordinate relationships. Stud Media Commun. 2013;1(2):11-24. doi: http://dx.doi.org/10.11114/smc.v1i2.122 
25. Silva SS, Assis MMA, Santos AM. The nurse as the protagonist of care management in the Estratégia Saúde da Família: different analysis perspectives. Texto Contexto Enferm. 2017;26(3):e1090016. doi: http://dx.doi.org/10.1590/0104-07072017001090016

26. Canesqui AM, Barsaglini RA. Social support and health: standpoints from the social and human sciences. Ciênc Saúde Coletiva. 2012;17(5):1103-14. doi: http://dx.doi.org/10.1590/S1413-81232012000500002

27. Broca PV, Ferreira MA. Nursing staff and communication: contributions to nursing care. Rev Bras Enferm. 2012;65(1):97-103. doi: http:// dx.doi.org/10.1590/S0034-71672012000100014

28. Matt SB, Fleming SE, Maheady DC. Creating disability inclusive work environments for our aging nursing workforce. J Nurs Adm. 2015;45(6):325-30. doi: http://dx.doi.org/10.1097/NNA.0000000000000208 